\title{
HABITAT SELECTION OF INSECTIVOROUS BIRDS IN WESTERN BLACK SEA REGION OF TURKEY
}

\author{
BESKARDES, V. \\ Istanbul University - Cerrahpasa, Faculty of Forestry, Forest Entomology and Protection \\ Department, Istanbul, Turkey \\ (e-mail:vkardes@istanbul.edu.tr)
}

(Received 21 ${ }^{\text {st }}$ Apr 2020; accepted 29 $9^{\text {th }}$ Jul 2020)

\begin{abstract}
Understanding the habitat preferences of species is crucial to their conservation. Bird species in particular are thought to be strongly affected by habitat structure (canopy cover, tree height, etc.) and land use. Due to their importance in pest control in both natural and agricultural environments, the habitat preference of insectivorous birds in particular was assessed by this study. To this end, the abundance and the number of insectivorous birds across different habitat types and land uses were investigated in Western Black Sea Region of Turkey. A total of 78 insectivorous bird species belonging to 6 orders and 25 families were identified and 10635 individuals were counted in the study. Canopy cover, vegetation layer, elevation and habitat heterogeneity positively affected insectivorous bird diversity. Forest management plans should include precautions to ensure the maintenance of tree canopy and habitat heterogeneity. Natural vegetation should be protected and improved when lacking in farmlands and urban areas in order to ensure the conservation of bird species.
\end{abstract}

Keywords: bird habitat, vegetation layer, canopy cover, elevation, insectivorous bird

\section{Introduction}

There is much research related to habitat preferences of birds, providing insight into the impacts of natural and human factors that affect birds (Heikkinen et al., 2004). Habitat use is associated with mechanisms responsible for habitat selection (Morris, 1987). Rosenzweig (1981) revealed three important concepts concerning the habitat selection of bird species; generalist, specialist and opportunist. Habitat selection is a hierarchical process of behavioral responses that results in a use of resources out of proportion to their availability, influencing the fitness and survival of individuals (Jones, 2001; Broughton et al., 2012). Individuals can forage in suitable habitats where probability of survival is higher. Species that exploit all habitat types are thought of generalists. Since the density of resources among habitat types is different and provides a diversity with food resources (MacArthur and Levins, 1967; Morris, 1987).

Vegetation gives terrestrial habitats their characteristic physical structure. That spatial structuring or physiognomy has repeatedly been shown to be important in determining the distribution and abundance of birds in habitat selection and, presumably, as an ultimate factor by its association with critical resources such as food, nesting sites, or cover from predators (Hilden, 1965; Rotenbery and Wiens, 1980). Forest structure (canopy, tree height, vertical and horizontal stratification and diversification) in particular has a strong relationship with bird diversity. And high insect abundance and diversity being responsible for greater bird diversity and numbers observed in tall and dense stands (Beskardes et al., 2018a).

Bird species are evaluated as ecological indicators of habitat or ecosystems (Canterbury et al., 2000). They are among the animals that consume insects most (Perrins, 1987; Bezzel, 1996) and particularly play significant role in ecosystems (Turan, 1990; Ozkazanc, 2016). Because of prey size, energy and other nutrients 
(Kaspari and Joern, 1993), granivorous birds feed on insects during their breeding season, while insectivorous birds feed on insects as long as they can find them (Arslangundogdu, 2010). Insects and other invertebrates provide proteins and nitrogen in bird diets, which are particularly important for growing birds (Stratford and Şekercioğlu, 2015). It has been proven that birds can significantly reduce the abundance of herbivorous insects in tropical, temperate, and boreal forests. Birds in forests account for $75 \%$ of the annual prey consumption of the world's insectivorous birds $\left(\approx 300\right.$ million tons year $\left.{ }^{-1}\right)$ (Nyffeler et al., 2018).

The foraging strategies can be different among bird species (Yard et al., 2004). Insectivorous birds can be classified as aerial (predominantly feeding on insects in the air) and terrestrial/arboreal that classifying is based on foraging strategy (Kissling et al., 2012). The number of terrestrial insectivorous bird is 4903 (55\% of all birds) species and aerial insectivores 225 species on earth. (Kissling et al., 2012). Insectivorous birds have diverse strategies for finding insects. Terrestrial insectivores, for instance, forage in the leaf litter but there are various methods of foraging in litter including leaf tossing, searching the surface or searching under living leaves while walking across the surface of leaf litter (Stratford and Stouffer, 2013).

Based on the importance of insectivorous birds in ecosystems, in this study, it was aimed to determine the number of insectivorous bird species, abundance and their habitat preference, and to make recommendations for habitat management of important insectivorous bird species to landowners and wildlife managers in the region.

\section{Material and Methods}

\section{Study area}

This study was conducted in Duzce province which is located at the western border of the Western Black Sea Region of Turkey (Figure 1). Surface area of Duzce is 264296 ha. Forest covers around 138460 ha, farmlands, meadows and wetlands 108425 ha, settlements 17411 ha. Deciduous (beech, hornbeam, oak, chestnut, linden) forests, coniferous (fir, yellow pine, black pine) forests, and a mixture of these are all under the influence of the Black Sea climate. Forest areas are found in regions where groups of high slopes rise to $1830 \mathrm{~m}$ (Karduz plato) (Keten, 2017). Kucuk Melen, Ugursuyu, Asarsuyu, Aksu, Buyuk Melen rivers and Efteni Lake are the important wetlands surrounding with agricultural and rural areas. The average temperature is $13.3{ }^{\circ} \mathrm{C}$ and the average rainfall is $816 \mathrm{~mm}$ (1950-2014). The climate (according to Thornthwaite) is classified as moist, with mesothermal water moderately deficient in the summer and a summer evaporation rate of 51\% (MGM, 2018).

\section{Samplings}

Sampling was conducted from middle of the March to August of 2014 in 351 sampling points (Figure 1). Bird observations were done during the morning from sunrise to 11:00 hours and from 15:00 hours to sunset. Only breeding insectivorous birds were considered for this study. Counts were made by directly observing and hearing sounds of birds in transect lines with two belts in the sampling plots (Bibby et al., 2000) which were recorded on bird cards. The length of the transect lines is $100 \mathrm{~m}$ in forests, the width of the transect is $100 \mathrm{~m}$ in forest habitats $(25 \mathrm{~m}$ for each belts), 
$200 \mathrm{~m}$ for settlement/farmland habitats (50 m for each belts) (Figure 2). A total of 819 ha area $(0.31 \%)$ was surveyed in study area.

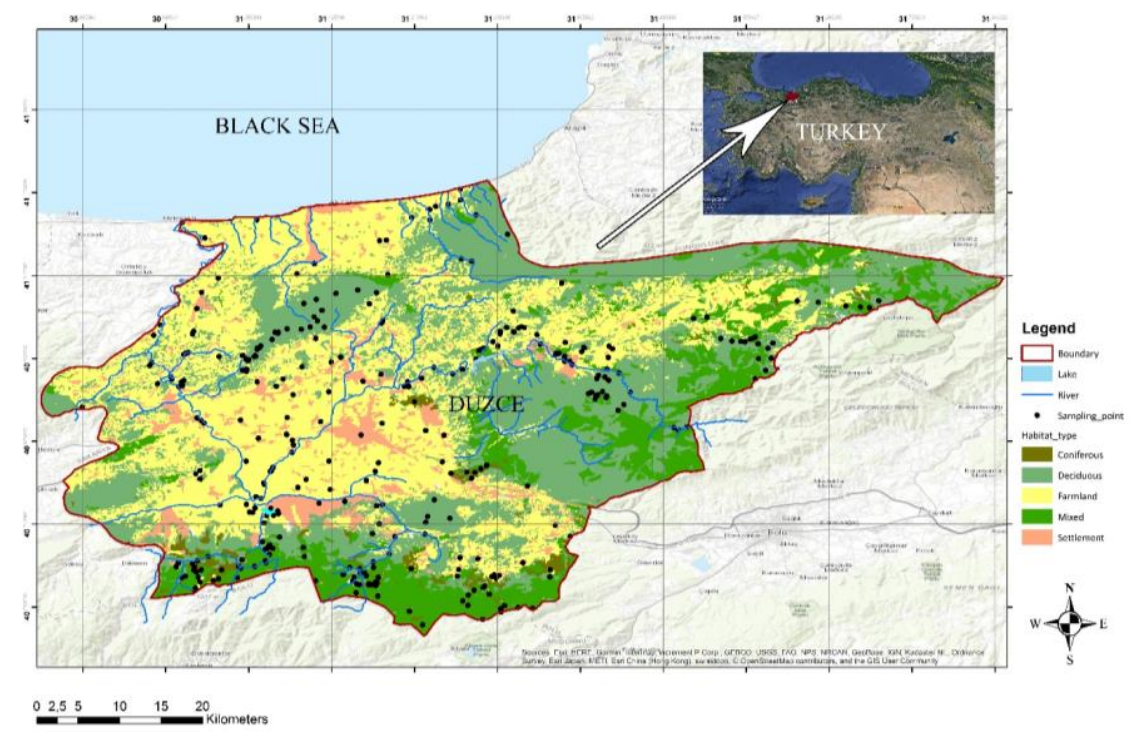

Figure 1. Duzce province and Sampling points
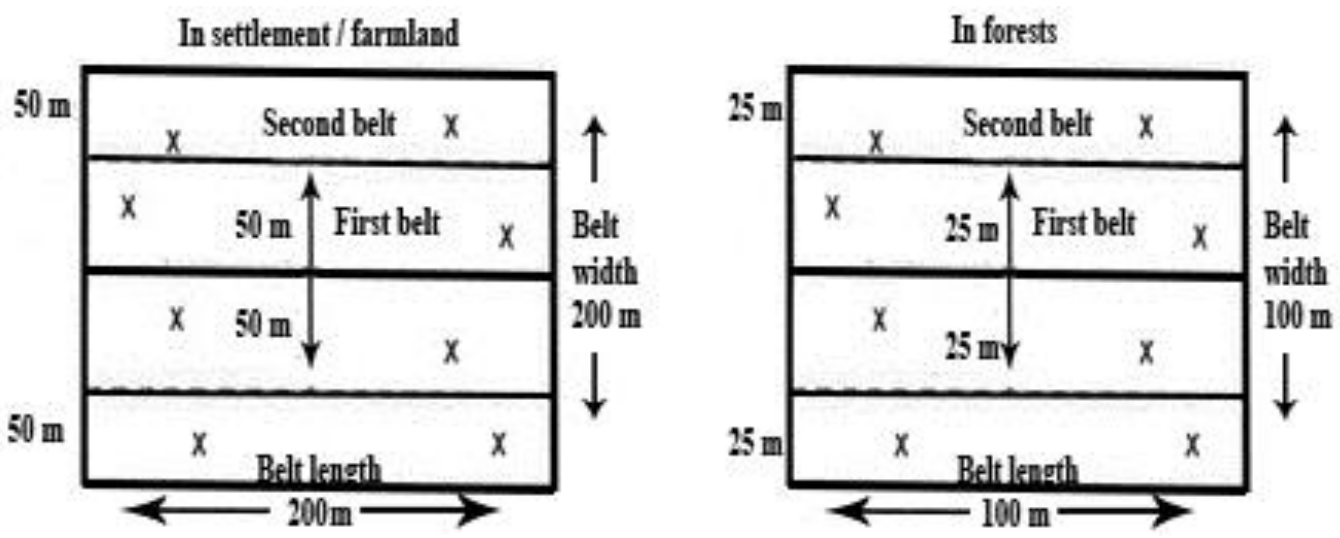

Figure 2. In Settlement and Farmland (belt width 200 m) / In Forest (belt width $100 \mathrm{~m}$ )

GPS was used to determine sampling plot coordinates and elevation. In addition, habitat types of localities were recorded. The species identification was based on several field guides (Heinzel et al., 1995; Mullarney et al., 1999; Hume, 2002) and the insectivorous bird species were categorized according to Perrins (1987). The map of Duzce province and sampling points was prepared by ARCGIS 10.2.

\section{Data analysis}

The sampling plots were classified as coniferous forests, deciduous forest, mix forest, farmland and settlement. Insectivorous bird species richness was calculated as the total number of species recorded at the plots, and species diversity using the Shannon-Wiener index (Magurran, 1988). We used descriptive statistics and one-way analysis of variance (ANOVA) to compare number of bird species with habitat types. 
Constrained Correspondence Analysis (CCA) was conducted to assess the habitat types based on all parameters measured in the study (Legendre and Legendre, 2003). CCA was conducted in habitat variables; latitude, longitude, distance to settlement (m), vegetation layer, elevation (a.s.l., m), canopy cover (\%) and aspect.

In evaluating the relationship between bird species and habitat factors using CCA, only sites that were sampled at least 10 times on different days were used in order to avoid observation bias. The similarity in habitats among the five habitat types were estimated with Ward's methods that uses minimum variance values and classifies by hierarchical clustering (Murphy, 2004). Venn diagram were used to analyze in habitat selection of birds. Significance was set at the $\alpha=0.05$ level. All analysis was conducted using Program R Gui (R Development Core Team, 2018).

\section{Results}

A total of 78 insectivorous bird species belonging to 6 orders and 25 families were identified and 10635 individuals were counted. Although, farmlands had more bird species abundance (61 species) and 6256 individuals. The conifer habitats had lower bird species abundance (15 species) and 119 individuals. However, among habitat types, the mix forest habitats had the most bird diversity (2.9), the settlements had the lowest (0.75) (Table 1). The number of insectivorous birds per ha was 17.02 in settlements, 13.03 in farmlands, 11.01 in mix forests, 9.90 in deciduous forest and 5.41 in conifer forests (Table 2). All bird species in the study and the habitats in which they were recorded are listed in the supplementary materials.

Table 1. Biodiversity indexes for each habitat observed in the Duzce province study area

\begin{tabular}{c|c|c|c|c|c|c}
\hline & Conifer F. & Deciduous F. & Mix F. & Farmland & Settlement & Total \\
\hline Total species & 15 & 39 & 47 & 61 & 27 & 81 \\
Total individuals & 119 & 851 & 958 & 6256 & 2451 & 10635 \\
S_W Index & 2.16 & 2.79 & 2.9 & 1.35 & 0.75 & 1.83 \\
Evenness & 0.8 & 0.76 & 0.75 & 0.33 & 0.23 & 0.42 \\
\hline
\end{tabular}

Table 2. Estimated insectivorous bird number and density at each habitat observed in the Duzce province study area

\begin{tabular}{c|c|c|c|c|c}
\hline Habitat type & $\begin{array}{c}\text { Habitat } \\
\text { (Area - ha) }\end{array}$ & $\begin{array}{c}\text { Sampling } \\
\text { number }\end{array}$ & $\begin{array}{c}\text { Sampling area } \\
\text { (ha) }\end{array}$ & $\begin{array}{c}\text { Total } \\
\text { individual }\end{array}$ & $\begin{array}{c}\text { Bird number per } \\
\text { ha }\end{array}$ \\
\hline Conifer & 4341.5 & 22 & 22 & 119 & 5.41 \\
Mix & 38155.7 & 87 & 87 & 958 & 11.01 \\
Deciduous & 95963.2 & 86 & 86 & 851 & 9.90 \\
Farmland & 108425.3 & 120 & 480 & 6256 & 13.03 \\
Settlement & 17410.5 & 36 & 144 & 2451 & 17.02 \\
Total & 264296.2 & 351 & 819 & 10635 & 12.99 \\
\hline
\end{tabular}

The results of variance analysis comparing 5 variables revealed that factors such as vegetation layer, canopy closure, elevation and distance to settlement were effective in the habitat selection of birds $(<0.001)$ (Table 3). On the contrary, aspect was found to be insignificant $(\mathrm{P}=0.171)$. 
Table 3. Descriptive statistics (Mean and standard error) and ANOVA

\begin{tabular}{c|c|c|c|c|c|c|c}
\hline & Conifer F & Deciduous F & Mix F & Farmland & Settlement & F & P \\
\hline $\begin{array}{c}\text { Number of } \\
\text { Species }\end{array}$ & $2.50 \pm 0.40$ & $3.53 \pm 0.20$ & $3.68 \pm 0.20$ & $3.18 \pm 0.46$ & $3.90 \pm 0.51$ & 0.909 & 0.459 \\
Number of & & & & & & & \\
individual & $7.44 \pm 1.94$ & $7.81 \pm 0.86$ & $8.40 \pm 0.69$ & $63.84 \pm 52.68$ & $116.71 \pm 97.15$ & 1.119 & 0.347 \\
Vegetation layer & $1.88 \pm 0.05$ & $1.38 \pm 0.05$ & $1.39 \pm 0.05$ & $1.92 \pm 0.06$ & $1.67 \pm 0.11$ & 17.54 & $<0.001$ \\
Canopy closure & $2.44 \pm 0.18$ & $2.67 \pm 0.05$ & $2.40 \pm 0.06$ & 1.00 & 1.00 & 191.00 & $<0.001$ \\
Aspect & $2.19 \pm 0.23$ & $2.10 \pm 0.09$ & $1.82 \pm 0.08$ & $2.03 \pm 0.09$ & $2.00 \pm 0.20$ & 1.61 & 0.171 \\
Elevation & $840 \pm 127$ & $642 \pm 29$ & $1088 \pm 36$ & $283 \pm 27$ & $257 \pm 54$ & 90.61 & $<0.001$ \\
Distance & $1558 \pm 311$ & $2636 \pm 202$ & $3039 \pm 331$ & $721 \pm 79$ & 0 & 18.51 & $<0.001$ \\
Settlement & & \multicolumn{1}{|c|}{} & & & &
\end{tabular}

The prepared Venn diagram shows that 11 of the bird species (Delichon urbicum, Erihtacus rubecula, Motacilla alba, Periparus ater, Cyanistes caeruleus, Parus major, Poecile palustris, Phoenicurus ochruros, Phylloscopus collybita, Turdus merula, Turdus philomelos) were common species, and observed in all habitat types. The highest bird species diversity was identified with 61 taxa in agricultural areas followed by 47 taxa in mixed forests. The least number of species was determined in coniferous forests with 15 taxa. Additionally, there was no insectivorous bird species that preferred only coniferous forests (Figure 3).

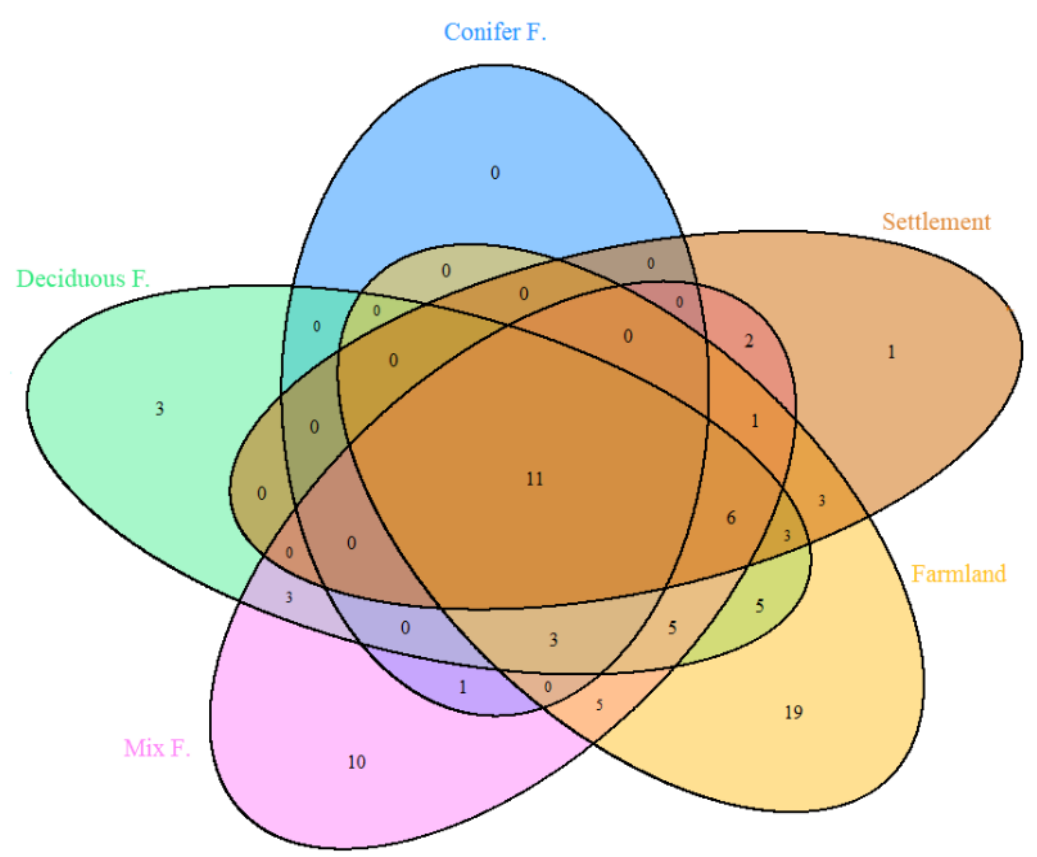

Figure 3. Venn diagram of bird species' number with habitats

Farmlands and settlements-showed similarity in terms of bird species diversity and abundance (Figure 4). Overall, forested plots had similar bird community composition (Figure 4). However, within forest areas, deciduous and mixed forests were clustered together and slightly apart from coniferous plots in terms of bird composition (Figure 4). 


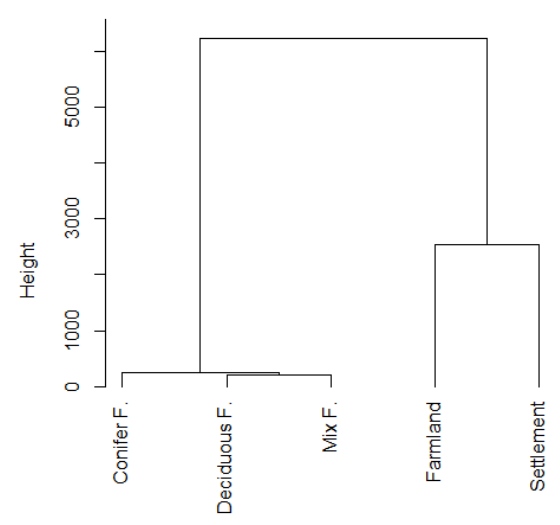

Figure 4. Cluster analysis (Ward's Method)

In the study, there were 23 bird species that were observed more than 10 times. The most important factors in driving bird species composition were elevation and cover followed by vegetation layer (Figure 5). However, several bird species including Turdus merula, Muscicapa striata, Erithacus rubecula, Picus viridis, Parus major, Cyanistes caeruleus, Motacilla cinerea, and Dendrocopos major being centered in the CCA graphic were not strongly affected by those factors. Farmlands and settlements included many of the same bird species such as Sturnus vulgaris and Delichon urbicum. Hirundo rustica and Lanius collurio were affected by vegetation layers in open areas (Figure 5), and farmlands and settlements had the most individual numbers. Cover and distance to settlement in deciduous forests positively affected bird species richness. Periparus ater and Poecile palustris were the species most affected by altitude and preferred mixed forests.

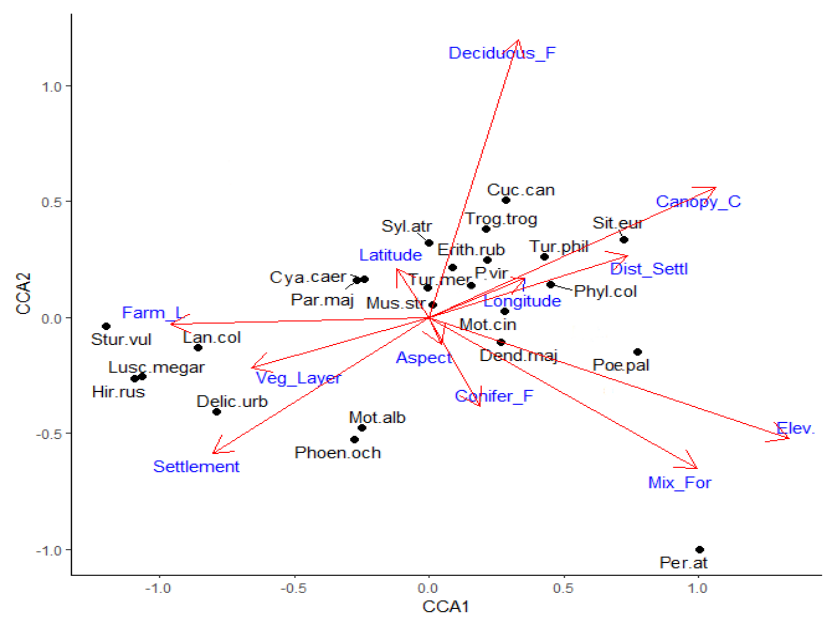

Figure 5. Constrained Correspondence Analysis for insectivorous birds (Sturnus vulgaris Stur.vul., Lanius collurio -Lan.col., Luscinia megarhynchos - Lusc.megar., Hirundo rustica Hir.rus., Delichon urbicum - Delic.urb., Phoenicurus ochruros - Phoen.och., Motacilla alba Mot.alb., Cyanistes caeruleus - Cya.caer., Parus major-Par mar., Muscicapa striataMus.str., Turdus merula - Tur.mer., Sylvia atricapilla - Syl.atr., Erithacus rubeculaErith.rub., Picus viridis - P.vir., Motacilla cinerea - Mot.cin., Dendrocopos major-Dend.maj., Poecile palustris - Poe.pal., Periparus ater-Per.atr., Phylloscopus collybita-Phyl.col., Turdus philomelos - Tur.phil., Troglodytes troglodytes - Trog.trog., Cuculus canorus Cuc.can., Sitta europaea - Sit.eur.) 


\section{Discussion}

Deciduous and mix forests in Duzce province were composed of similar bird species, and differentiated from coniferous forests. Agricultural areas and settlements also has many of the same species, which were not common in forested areas. Bird abundance per hectare was lowest in conifer forests, the highest in settlements, and moderate for deciduous, mix forests and agricultural areas. Oak forests in our region had higher bird density than that observed in Sitka spruce plantations in Ireland (Sweney et al., 2010), and had higher bird species richness than other pine stands in Turkey (Bergner et al., 2015). Species richness were found to be higher in edge habitats and open areas on forest exteriors rather than forest interior in Belgium (Paquet et al., 2006). Similar to my findings, bird species richness was significantly higher in mixed oak-pine forests than in pinewoods in Spain (Diaz, 2006). Duzce province is a developing region with much of the landscape being composed of rural areas. A major lake in the region, Efteni lake, is located within the settled areas of the city of Duzce, and most rivers in the region pass through settlement and agricultural areas. In Romania, rivers were shown to have positive effects on the bird community composition by providing of many resources in Romania (Domokos and Domokos, 2016). Thus the concentration of natural water features may explain the greater insectivorous bird density in settlements and agricultural areas in Duzce province.

In this study, 10635 individuals were counted, and 78 insectivorous bird species recorded that constitutes $42.6 \%$ of 183 bird species known for the region (Nuhungemisi, 2019). Breeding bird species density ranged between 8.9 and 21.4 birds in deciduous forests in USA (Anderson, 1970; Holmes et al., 1986). In this study, the density of breeding birds was found also within that range (Table 2). Birds hold down arthropods or insects' population by eating adults, larvae, pupae and eggs. While looking for these nutrients, birds find insects under tree barks, among wood litter, in the soil and from mud (Turan, 1990). Insectivorous birds consume 404.6 million tons of insects and $2.7 \times 10^{18}$ joule year ${ }^{-1}$ in the world (Nyffeler et al., 2018). Thus, insectivorous birds are highly important biological agents that protect agricultural areas and the other ecosystems from pest outbreaks.

Although 61 insectivorous bird taxa were detected in agricultural areas, the lowest biodiversity was found in these ecosystems. The birds forming large groups especially Sturnus vulgaris and Hirundo rustica, caused a lower Shannon and Evenness value in agricultural and settlements. Nutrition plays important role in the habitat preference of Sturnus vulgaris (Tinbergen, 1980). Albeit, they are feeding on different habitat types, rural and agricultural areas provide perfect feeding habitats. For this reason, those areas are included more individuals of $S$. vulgaris.

In ecosystems, the coexistence of generalists' bird species depended strongly on the species' dispersal abilities (Büchi and Vuilleumier, 2014). In this study, 11 insectivorous birds were observed across all habitat types (Delichon urbicum, Erithacus rubecula, Motacilla alba, Periparus ater, Cyanistes caeruleus, Parus major, Poecile palustris, Phoenicurus ochruros, Phylloscopus collybita, Turdus merula, Turdus philomelos). These birds can be described as common species. Since they can be found on any kind of habitat and are less affected by habitat fragmentation and disturbance than other species (Devictor et al., 2008). Although Phylloscopus collybita and Turdus philomelos could be found in all habitats, they were mostly observed in deciduous forests with high canopy cover, and preferred to stay away from settlements. The four tit species Parus major, Periparus ater, Cyanistes caeruleus, Poecile palustris also 
observed in all habitat types. $P$. ater were closely associated with coniferous forests and $P$. palustris with deciduous forests (Beskardes et al., 2018b). P. ater and P. palustris were affected by elevation. In addition, both species preferred mixed forest than conifer and deciduous forests. Mix forests has provided more food and cover than pure coniferous forests for insectivorous birds, especially in breeding season.

A total of 23 bird species was detected more than 10 times. The forested areas further away from settlements have greater insectivorous bird number and species. Especially, Sitta europaea were affected by canopy cover mostly. Farmland and rural area species such as Sturnus vulgaris, Delichon urbicum, Hirundo rustica, Lanius collurio has affected positively by habitat patches. Plant height diversity (Lancaster and Rees, 2011) and horizontal layer (stratification) in habitat affected birds' population positively (Arslangundogdu and Y1lmaz, 2011). The fact that species richness was most strongly related to understory cover emphasizes the importance of woodland vegetation structure to birds in my study region (Sweney et al., 2010). Canopy cover, vegetation layer, elevation and heterogeneity of habitat in mix forests also positively affected insectivorous bird diversity. Complex vegetation structure and floristic composition heterogeneity increase niche diversity, which is thought to also increase avian diversity (Diaz, 2006).

In Duzce province, intensive agricultural activities are carried out and also 120 tones pesticides (insecticide, herbicide, fungicide etc.) are used every year (PDEU, 2018). It is known that farmland bird population has declined in Europe in the past three decades with agricultural intensification and the use of pesticides are known to be a major threat to farmland birds (Hallmann et al., 2014). The higher bird density in agricultural areas and settlement observed in this study should not be interpreted as a basis for a lack of threat to bird species in these areas as agricultural practices may have effects on birds on a regional scale while providing good habitat for certain species. Long term bird censuses are needed in agricultural and surrounding areas in order to understand how the application of pesticides or other agricultural practices are effecting bird diversity in Duzce Province.

\section{Conclusion}

One of the most important areas for bird species in Duzce is the Efteni lake and the Melen river. Especially in agricultural areas, these water resources are the most important factors that increase the biodiversity and bird species, and their preservation is of utmost importance to wildlife. Birds need cover to breed and to raise their fledglings successively during breeding. For this reason, maintenance of forest and shrub cover are also critical for bird conservation. Increasing vegetation cover and layers in marginal areas increases stratification and edges which effects birds positively. Thus, wildlife managers and landowners should be supported to protect vegetation layers (bushes, wooded etc.) in farmlands for birds, and landowners should be warned not to use pesticides during bird breeding seasons. In addition, the future studies are necessary to investigate the effects of pesticide using on birds in agricultural areas and how agricultural practices affect the diversity of bird species.

Acknowledgements. This study was supported by the Düzce University Scientific Research Projects (DU-BAP). I would like to thank Akif KETEN, Zeynel ARSLANGUNDOGDU and Ergun BACAK for their valuable help. I also thank Kemal Burak PEKIN for helping to evaluate and improve the article. And 
special thanks to my wife Ozlem BESKARDES who provided me with a peaceful and perfect working environment at home and helped me with everything.

\section{REFERENCES}

[1] Anderson, S. H. (1970): The Avifaunal Composition of Oregon White Oak Stands. - The Condor 72: 417-423.

[2] Arslangundogdu, Z. (2010): Presence of insectivorous birds in the forest area of Istanbul University, Turkey. - Journal of Environmental Biology 31: 197-206.

[3] Arslangundogdu, Z., Yilmaz, E. (2011): The Effects of Tree stand layers on Resident Bird Species in Belgrade Forest, Istanbul, Turkey. - Allgemeine Forst und Jagdzeitung 182(3-4): 25-29.

[4] Bergner, A., Avc1, M., Eryiğit, H., Jansson, N., Niklasson, M., Westerberg, L., Milberg, P. (2015): Influences of forest type and habitat structure on bird assemblages of oak (Quercus spp.) and pine (Pinus spp.) stands in southwestern Turkey. - 336: 137-147.

[5] Beskardes, V., Keten, A., Kumbasli, M., Pekin, B., Yilmaz, E., Makineci, E., Ozdemir, E., Zengin, H. (2018a): Bird composition and diversity in oak stands under variable coppice management in Northwestern Turkey. - iForest 11: 58-63.

doi: 10.3832/ifor2489-010 (online 2018-01-25).

[6] Beskardes, V., Keten, A., Arslangundogdu, Z., Anderson, J. T. (2018b): Habitat use by tit species in the Yuvacik Watershed, Turkey. - Fresenius Environmental Bulletin 27-12A: 9033-9039.

[7] Bezzel, E. (1996): Birds observation (Practical tips, protection of birds, Nestasistance). BLV Verlagsgesellschaft mbH München, 3-405-14007-5.

[8] Bibby, C. J., Burgess, N. D., Hill, D. A., Musto, S. H. (2000): Bird Census Techniques (Second Edition). - Academic Press, London.

[9] Broughton, R. K., Hill, R. A., Freeman, S. N., Bellamy, P. E., Hinsley, S. A. (2012): Describing habitat occupation by woodland birds with territory mapping and remotely sensed data: An example using the marsh tit (Poecile palustris). - The Condor 114(4): 812-822.

[10] Büchi, L., Vuilleumier, S. (2014): Coexistence of Specialist and Generalist Species Is Shaped by Dispersal and Environmental Factors. The American Naturalist. - 185(5): 612624.

[11] Canterbury, G. E., Martin, T. E., Petit, D. R., Petit, L. J., Bradford, D. F. (2000): Bird Communities and Habitat as Ecological indicator of Forest Condition in Regional Monitoring. - Conservation Biology 14(2): 544-558.

[12] Devictor, V., Julliard, R., Jiguet, F. (2008): Distribution of specialist and generalist species along spatial gradients of habitat disturbance and fragmentation. - Oikos (Online Early) doi: 10.1111/j.2008.0030-1299.16215.x.

[13] Diaz, L. (2006): Influences of forest type and forest structure on bird communities in oak and pine woodlands in Spain. - Forest Ecol. Manag. 223(1-3): 54-65.

[14] Domokos, E., Domokos, J. (2016): Bird communities of different woody vegetation types from the Niraj Valley, Romania. - Turk J. Zool. 40: 734-742.

[15] Hallman, C. A., Foppen, R. P. B., van Turnhour, C. A. M., de Kroon, H., Jongejans, E. (2014): Declines in insectivorous birds are associated with high neonicotinoid concentrations. - Nature 511(7509): 341-343.

[16] Heikkinen, R. K., Luoto, M., Virkkala, R., Rainio, K. (2004): Effects of habitat cover, landscape structure and spatial variables on the abundance of birds in an agriculturalforest mosaic. - Journal of Applied Ecology 41: 824-835.

[17] Heinzel, H., Fitter, R., Parseow, J. (1995): Collins Pocket Guide to Birds of Britain and Europe, with North Africa and the Middle East. - Istanbul, 384p. 
[18] Hilden, O. (1965): Habitat selection in birds: A review. - Finnish Zoological and Botanical Publishing Board 2(1): 53-75.

[19] Holmes, R. T., Sherry, T. W., Sturges, F. W. (1986): Bird Community Dynamics in a Temperate Deciduous Forest: Long-Term Trends at Hubbard Brook. - Ecological Monographs 56(3): 201-220.

[20] Hume, R. (2002): Complete Bird of Britain and Europe. - RSPB, Dorling Kindersley, London.

[21] Jones, J. (2001): Habitat selection studies in avian ecology: a critical review. - Auk 118: 557-562.

[22] Kaspari, M., Joern, A. (1993): Prey choice by three insectivorous grassland birds: reevaluating opportunism. - Oikos 68: 414-430.

[23] Keten, A. (2017): Distribution and habitat preference of roe deer (Capreolus capreolus L.) in Düzce Province (Turkey). - Journal of the Faculty of Forestry Istanbul University 67(1): 22-28.

[24] Kissling, W. D., Şekercioğlu, Ç. H., Jetz, W. (2012): Bird dietary guild richness across latitudes, environments and biogeographic regions. - Global Ecology and Biogeography 21(3): 328-340.

[25] Lancaster, R. K., Rees, W. E. (2011): Bird communities and the structure of urban habitats. - Canadian Journal of Zoology 57: 2358-2368.

[26] Legendre, P., Legendre, L. (2003): Numerical ecology (2 ${ }^{\text {nd }}$ ed.). - Elsevier, Amsterdam, The Netherlands, 1006p. (online) URL:http://books.google.com/books?id=6ZBOAiDviQC.

[27] MacArthur, R. H., Levins. R. (1967): The limiting similarity, convergence and divergence of coexisting species. - American Naturalist 101: 377-385.

[28] Magurran, A. E. (1988): Ecological diversity and its measurement. - Princeton University Press, 179p.

[29] MGM (2018): The Directorate of Meteorology. - http://www.mgm.gov.tr/. Düzce climate data. (Accessed 21.01.2018).

[30] Morris, D. W. (1987): Ecological scale and habitat use. - Ecology 68(2): 362-369.

[31] Mullarney, K., Svenson, L., Zetterström, D., Grant, P. J. (1999): Bird Guide Grant: The Most Complete Field Guide to the Birds of Britain and Europe. - Harper Collins, London.

[32] Nuhungemisi (2019): Nuh'un Gemisi Ulusal Biyolojik Çeşitlilik Veritabanı. - Database of National Biodiversity of Turkey.

Online: http://www.nuhungemisi.gov.tr/Library/IlEnvanter, 17.12.2019.

[33] Nyffeler, M., Şekercioğlu, Ç. H., Whelan, C. J. (2018): Insectivorous birds consume an estimated 400-500 million tons of prey annually. - The Science of Nature 105: 47.

[34] Ozkazanc, N. K. (2016): The Importance of Birds in Biological Control and Insectivorous Bird Species Determined in Bartın. - Journal of Bartin Faculty of Forestry 18(2): 55-64.

[35] Paquet, J., Vandevyvre, X., Delahaye, L., Rondeux, J. (2006): Bird assemblages in a mixed woodland-farmland landscape: The conservation value of silviculture-dependant open areas in plantation forest. - Forest Ecology and Management 227: 59-70.

[36] PDEU (2018): Environmental Status of Duzce Province, 2018. - Provincial Directorate of Environment and Urbanization (in Turkish).

online: https://webdosya.csb.gov.tr/db/ced/icerikler/duzce_2018_-cdr_rev-ze20190806102512.pdf (Access: 29.12.2019).

[37] Perrins, C. (1987): Vögel (Biologie + Bestimmen + Ökologie) (Birds-Biology, Description and Ecology). - Pareys Naturführer Plus, Hamburg und Berlin, Germany, 320p. (in German).

[38] R Development Core Team (2018): R: A Language and Environment for Statistical Computing. R Foundation for Statistical Computing. - Vienna. https://www.Rproject.org.

[39] Rosenzweig, M. L. (1981): A theory of habitat selection. - Ecology 62(2): 327-335. 
[40] Rotenberry, J. T., Wiens, J. (1980): Habitat Structure, Patchinnes, and Avian Communities in North American Steppe Vegetation: A Multivariate Analysis. - Ecology 61(5): 1228-1250.

[41] Stratford, J. A., Stouffer, P. C. (2013): Microhabitat associations of terrestrial insectivorous birds in Amazonian rainforest and second-growth forests. - Journal of Field Ornithology 84(1): 1-12.

[42] Stratford, J. A., Şekercioğlu, H. A. (2015): Birds in Forest Ecosystems. - In: Peh, K. S.H., Corlet, R. T., Bergeron, Y. (eds.) Routledge Handbook of Forest Ecology. Rootledge Handbooks Series, ISBN-13: 978-0415735452.

[43] Sweney, O. F., Wilson, M. W., Irwin, S., Kelly, T. C., O’Halloran, J. (2010): Are bird density, species richness and community structure similar between native woodlands and non-native plantations in an area with a generalist bird fauna?. - Biodivers. Conserv. 19: 2329-2342.

[44] Tinbergen, J. M. (1980): Foraging Decisions in Starlings (Sturnus vulgaris L.). - Ardea 69: 1-67.

[45] Turan, N. (1990): Türkiye'nin Av ve Yaban Hayvanları. Kuşlar 2. Kitap (The game and wild animals of Turkey, Birds Volume 2). - Orman Genel Müdürlüğü, Eğitim Daire Başkanlığı, Yayın ve Tanıtım Şube Müdürlüğü, Ankara, 274p. (in Turkish).

[46] Yard, H. K., Van Riper, C., Brown, B. T., Kearsley, M. J. (2004): Diets of insectivorous birds along the Colorado River in Grand Canyon, Arizona. - The Condor 106: 106-115.

\section{SUPPLEMENTARY MATERIAL}

Species list and individual numbers of birds

\begin{tabular}{|c|c|c|c|c|c|c|}
\hline Habitat & Conifer & Deciduous & Mix & Farmland & Settlement & Total \\
\hline $\begin{array}{c}\text { Total Species } \\
\text { Total individual }\end{array}$ & $\begin{array}{c}15 \\
109\end{array}$ & $\begin{array}{c}39 \\
851\end{array}$ & $\begin{array}{c}47 \\
958\end{array}$ & $\begin{array}{c}61 \\
6256\end{array}$ & $\begin{array}{c}27 \\
2451\end{array}$ & $\begin{array}{c}81 \\
10635\end{array}$ \\
\hline $\begin{array}{c}\text { Tachymarptis melba } \\
\text { Apus apus }\end{array}$ & 0 & $\begin{array}{c}35 \\
5\end{array}$ & 2 & $\begin{array}{c}300 \\
2\end{array}$ & 5 & $\begin{array}{c}340 \\
9\end{array}$ \\
\hline Cuculus canorus & 1 & 9 & 11 & 2 & & 23 \\
\hline Upupa epops & & & 1 & 4 & & 5 \\
\hline Merops apiaster & & & & 180 & & 180 \\
\hline Dendrocopos major & 2 & 7 & 8 & 5 & & 22 \\
\hline Dendrocopos leucotos & & 1 & & & & 1 \\
\hline Dendrocopos medius & & 2 & & 2 & & 4 \\
\hline Dendrocopos minor & & 1 & & 2 & & 3 \\
\hline Dendrocopos sp. & & 2 & & & & 2 \\
\hline Dendrocopos syriacus & & 1 & & 6 & & 7 \\
\hline Dryocopus martius & & & 2 & & 1 & 3 \\
\hline Jynx torquilla & & & & & 3 & 3 \\
\hline Picus canus & & 3 & 5 & 1 & & 9 \\
\hline Picus viridis & & 3 & 4 & 5 & & 12 \\
\hline Picus sp. & & & 1 & 1 & & 2 \\
\hline Lanius collurio & & 3 & 2 & 44 & 3 & 52 \\
\hline Lanius excubitor & & & 1 & 1 & & 2 \\
\hline Lanius minor & & & 1 & & & 1 \\
\hline Oriolus oriolus & & & & 3 & 1 & 4 \\
\hline Periparus ater & 18 & 2 & 155 & 3 & 2 & 180 \\
\hline Cyanistes caeruleus & 1 & 14 & 8 & 14 & 2 & 39 \\
\hline Parus major & 3 & 117 & 68 & 140 & 39 & 367 \\
\hline Poecile palustris & 7 & 51 & 131 & 2 & 2 & 193 \\
\hline Parus lugubris & & & 1 & & & 1 \\
\hline Alauda arvensis & & & & 24 & & 24 \\
\hline Galerida cristata & & & & 5 & & 5 \\
\hline
\end{tabular}




\begin{tabular}{|c|c|c|c|c|c|c|}
\hline Habitat & Conifer & Deciduous & Mix & Farmland & Settlement & Total \\
\hline Lullula arborea & & & 2 & & & 2 \\
\hline Delichon urbicum & 40 & 29 & 30 & 224 & 150 & 473 \\
\hline Hirundo rustica & & 22 & 30 & 279 & 150 & 481 \\
\hline Hirundo daurica & & 2 & & 9 & & 11 \\
\hline Hirundo rupestris & & & 11 & & & 11 \\
\hline Riparia riparia & & & 50 & 33 & & 83 \\
\hline Cettia cetti & & & & 5 & & 5 \\
\hline Aegithalos caudatus & & & & 10 & & 10 \\
\hline Phylloscopus collybita & 14 & 122 & 115 & 30 & 6 & 287 \\
\hline Phylloscopus bonelli & & & & 2 & & 2 \\
\hline Phylloscopus throchiloides & & & 2 & & & 2 \\
\hline Phylloscopus trochilus & & & & 4 & 1 & 5 \\
\hline Iduna pallida & & & & 4 & & 4 \\
\hline Acrocephalus arundinaceus & & & & 8 & & 8 \\
\hline Acrocephalus melanopogon & & & & 5 & & 5 \\
\hline Acrocephalus schoenobaenus & & & & 6 & & 6 \\
\hline Acrocephalus scirpaceus & & & & 5 & & 5 \\
\hline Locustella luscinioides & & & & 4 & & 4 \\
\hline Sylvia atricapilla & & 18 & 6 & 13 & 1 & 38 \\
\hline Sylvia borin & & 4 & & 2 & & 6 \\
\hline Sylvia communis & & 1 & & 7 & 1 & 9 \\
\hline Sylvia melanocephala & & 2 & & & & 2 \\
\hline Sylvia nisoria & & & & 1 & & 1 \\
\hline Sylvia sp. & & & 4 & & 1 & 5 \\
\hline Regulus ignicapillus & & & 5 & & & 5 \\
\hline Regulus regulus & & & 11 & & & 11 \\
\hline Troglodytes troglodytes & 3 & 47 & 30 & 23 & & 103 \\
\hline Sitta europaea & & 14 & 9 & & & 23 \\
\hline Sitta krueperi & 8 & & 13 & & & 21 \\
\hline Certhia brachydactyla & & 4 & 2 & & & 6 \\
\hline Certhia familiaris & & & 1 & & & 1 \\
\hline Sturnus vulgaris & & 35 & & 4551 & 2040 & 6626 \\
\hline Turdus merula & 9 & 126 & 83 & 119 & 7 & 344 \\
\hline Turdus philomelos & 3 & 56 & 26 & 8 & 1 & 94 \\
\hline Turdus viscivorus & & & 8 & 1 & 3 & 12 \\
\hline Erithacus rubecula & 6 & 77 & 50 & 44 & 3 & 180 \\
\hline Luscinia megarhynchos & & 6 & 1 & 23 & 14 & 44 \\
\hline Muscicapa striata & & 9 & 8 & 6 & 2 & 25 \\
\hline Oenanthe oenanthe & & & 11 & & & 11 \\
\hline Oenanthe hispanica & & & & 2 & & 2 \\
\hline Oenanthe isabellina & & & & 2 & & 2 \\
\hline Phoenicurus ochruros & 3 & 3 & 3 & 7 & 4 & 20 \\
\hline Phoenicurus phoenicurus & & & & 1 & 1 & 2 \\
\hline Saxicola torquata & & 1 & 3 & 5 & 1 & 10 \\
\hline Saxicola rubetra & & & & 9 & & 9 \\
\hline Ficedula parva & & 1 & 1 & & & 2 \\
\hline Prunella modularis & & 3 & 1 & 4 & & 8 \\
\hline Motacilla alba & 1 & 4 & 22 & 32 & 7 & 66 \\
\hline Motacilla cinerea & & 9 & 17 & 9 & & 35 \\
\hline Motacilla flava & & & 1 & 3 & & 4 \\
\hline Anthus campestris & & & & 3 & & 3 \\
\hline Anthus pratensis & & & & 1 & & 1 \\
\hline Anthus spinoletta & & & 1 & & & 1 \\
\hline Anthus trivialis & & & & 6 & & 6 \\
\hline
\end{tabular}

